\title{
The Stipulative Imagination of Thom Gunn
}

\section{John Miller}

Thom Gunn is a British-American poet whose work has been praised and damned on both sides of the Atlantic. His first book of poems, Fighting Terms (1954), achieved considerable reputation in England, marking Gunn both as a member of "The Movement" then emerging in British letters and as an energetic young talent in his own right. English reviewers of Gunn's later volumes often decry what they consider a falling away from the wit, clarity, and prosodic control manifested in Fighting Terms. ${ }^{1}$ A number of American reviewers, on the other hand, have condescendingly dismissed Gunn as "a fashionable, rote versifier of some skill and intelligence" 2 and his poems as manufactured, minor allegories. ${ }^{3}$

Surprisingly few critics have noted an obvious fact of Gunn's career: that he has been the most self-consciously existential poet of either Great Britain or America in recent years. Whether his existentialism is a dilettantish dallying or a deeply experienced world-view, it affects both the substance and the technique of his poetry. Critics and reviewers, for the most part, have failed to confront this poetry on its own terms, preferring their own criteria or prejudices. If only his versification were not so stiff and traditional, or his language so abstract, American critics tell us, his poetry would measure up to his obvious intelligence. If only Gunn had maintained the technical brilliance of Fighting Terms, his early British admirers assert, his prosody would not have succumbed to creeping Americanism. Clearly Gunn cannot have the best of both worlds, British and American, when viewed from such perspectives.

My central assumption here, in contrast, is a simple one: that a poet writes what he does not merely to be fashionable or to display his ingenuity, but to enact and enunciate his attitudes toward human experience. Gunn's attitudes, derived from a consistently existential outlook, relate very closely to the kind of metaphor he develops in his poems: to the situations and persons he uses in these poems, and especially to the way he assigns value to or derives significance from them. However much Gunn may have been captivated by literary

\footnotetext{
1 See, for example, the reviews of Ronald Hayman ("Voznesensky, Elizabeth Bishop, Thom Gunn," Encounter, July 1968, p. 72) and Anthony Thwaite ("Good, Bad and Chaos," The Spectator, September 1, 1961, p. 298).

2 James Dickey, "The Suspect in Poetry or Everyman As Detective," Sewanee Review 68 (Autumn, 1960), p. 662.

3 Carol Johnson, "Four Poets," Sewanee Review 70 (Summer, 1962), p. 518; John Thompson, Poetry XCV (November, 1959), p. 111; Hayden Carruth, "Making It New," The Hudson Review XXI (Summer, 1968), p. 406.
} 
styles or traditions, the strengths and weaknesses of his poetry are not merely technical. They result from his sense of how meaning can be achieved, both in poetry and for the self-consciously isolated personality, in a world devoid of intrinsic significance.

What I call the "stipulative imagination," in Gunn's case, is that which asserts identity, metaphoric equivalence, or meaning within a provisional, often elaborately concocted situation. The stipulative imagination is one that passes from a situation perceived in terms of its sensible particularities to a more general "meaning" willfully imposed on that situation. In literature, the allegorical mode of perceiving and conveying significance seems related to the stipulative imagination; for this reason, probably, the term allegory has been applied disparagingly to Gunn's poetry. Yet most of the great allegorical works of the past -The Divine Comedy, The Faerie Queene, and Pilgrim's Progress, for example -are not merely stipulative. Their authors assumed, and probably most of their contemporary readers accepted, some ontological (or at least conventional) relationship between the designation or representative of a value and that value itself. In a society or life without pre-existing values, however, it is the isolated individual will or imagination that asserts meaning for a set of circumstances. Will or volition is a primary faculty not only for the existentially oriented self, but also for the stipulative poet. To define oneself, or to create some metaphoric extension of meaning for particular circumstances, is to assert or stipulate. Such assertion, in Gunn's poetry, often seems a precious or desperate exercise of will in the face of apparent meaninglessness.

Either the metaphoric equivalences or the semi-fictive personae of Gunn's poems often announce their significance in an explicit yet provisional manner. It is as if a mathematician, establishing the symbols with which he must work, were to say: "Let $\mathrm{X}$ stand for one referent, let $\mathrm{Y}$ stand for another, and let it be understood that these values for $\mathrm{X}$ and $\mathrm{Y}$ exist only within the specific context of this problem."

The mathematician legitimately deals with abstractions: sheer quantifications shorn of substance, numerical attributes without any necessary referents in the realm of physical things or events. The stipulative poet, by contrast, must somehow mediate between things and meanings, appearances and significances, the "vehicle" of a metaphor and the "tenor" or ultimate import that the metaphor should convey. Gunn's early poems, as products of a stipulative imagination, tend toward abstraction. Many are elaborately evolved constructs in which some kind of generalized meaning attaches to the particulars of experience and to the experiencer himself. In some cases it seems that Gunn has started with general ideas and has struggled to embody them: to provide experiential basis for otherwise abstract dichotomies or concepts. Sensations, gestures, perceptions, and actions become potential embodiments of meaning or personal identity, selfconsciously arrayed by the poet or his personae as emblems for stipulated significance. As Gunn clearly indicates, no deity or Emersonian Oversoul provides ontological basis for their possible meanings; nor does any communal consensus of belief. When a reviewer complained that most of the poems in Gunn's second 
volume (The Sense of Movement, 1957) were "manufactured things that pass for poetry,"4 he was merely playing his variation upon a statement that Gunn himself had asserted in the initial poem of that volume:

Men manufacture both machine and soul, And use what they imperfectly control.5

Since meaning is so arbitrary, transient, or problematical a goal in Gunn's early poetry, it follows that the definition of both words and persons is often a self-conscious assertion, a willful posing of tentative, precarious significance. The wit and energy of such assertions notwithstanding, they often appear as artificial strategies utilized in the absence of any natural relationship between human cognition and the instruments or objects of its awareness.

As perhaps I have already suggested, Gunn's earlier poetry differs from his more recent work and should not become either a criterion or an excuse for dismissing it. To date there are five volumes of Gunn's poetry: after Fighting Terms and The Sense of Movement, My Sad Captains (1961), Touch (1967), and Moly (1971). Reading all five volumes, one recognizes important shifts and developments in Gunn's career. His basic existential assumptions remain fairly constant, yet his later poems emerge with different strategies and values in the face of these assumptions. My focus here, however, is on the first three volumes.

Fighting Terms introduces a stock persona of Gunn's verse, the self-conscious, isolated individual, often poised painfully between action and reflection. In certain poems of this volume, Gunn assumes personal isolation as his starting point and then explores various modes of escaping or mitigating this separateness. Other poems, by contrast, move almost in the opposite direction. To relate with or feel for others is to forego self-sufficiency, to risk misunderstanding and emotional vulnerability, to expose one's toughly asserted social identity to the corrosive awareness of another consciousness. Thus isolated self-sufficiency is both a curse and a blessing: an armor to contain or defend one's own skeptical intelligence, and a loss of opportunity to exercise one's personality on Others and Otherness.

A recurrent metaphoric vehicle for this dilemma is the politician or political state. Each of these embodiments of the isolated individual is basically selfinterested. Yet each must enter into elaborate, disingenuous negotiations or warfare with a constituency, a neighboring state, or a foreign power. Each is aware that his self-conscious machinations and willfulness are likely to encounter equally devious resistance, yet each must proceed under the guise of righteousness or good will.

Such poems as "To His Cynical Mistress," "The Right Possessor," "The Court Revolt," "Captain in Time of Peace," "The Beach Head," and to a lesser extent

4 Thompson, op. cit., p. 111.

5 Thom Gunn, "On the Move," The Sense of Movement (London: Faber \& Faber, 1957), p. 11. All other poems footnoted are Gunn's. 
"The Wound"-all in Fighting Terms-use a political-diplomatic-military fable to explore the plight of an existential desperado or individual wooer. A strong similarity exists between these poems and some of Auden's early works which utilize the Spy or Secret Agent as their personae and a quasi-political dilemma as their central metaphor.6 Gunn, moreover, seems influenced by another of Auden's allegorical devices, that of the "psychic landscape," which, as we shall see, appears in "The Wound."

The major limitation of these pseudo-political fables is not their arbitrary, imposed connection between vehicle and tenor, their patent cleverness, but the limited range of their central metaphors. Instead of enriching or extending the meanings of their poems, these metaphors restrict or arrest significance. Let me put the matter in more general terms. The relation between vehicle and tenor, in metaphor, ideally involves the progression or enlargement of awareness from a particular instance to a more general implication. Vehicle is to tenor as specific understanding or appreciation is to a more extended awareness. Metaphor, in this case, transfers and extends our apprehending focus from a smaller to a larger or richer framework of significance. Or at least it enables a dynamic interplay between two realms of human activity. Auden's best political-psychological metaphors, for example, allow such interplay between the personal and the social orders of being; one realizes that it is not only the divided or ambivalent commitments of the individual psyche that appear in a poem, but also the social and political ambience in which divided loyalties are extended and reinforced. Gunn's poems such as "To His Cynical Mistress" and "The Beach Head," on the other hand, use an ostensibly political situation only as a stipulated emblematic framework, one with no other interest or reality than as a vehicle for Gunn's unremitting focus on individual self-consciousness in its relation to another such consciousness. A spurious social macrocosm shrinks, in effect, to a microcosm of alienated individuality. Perhaps this is something of what Martin Dodsworth meant when he wrote of the "anxious containment of thought" within the poems of Fighting Terms. ${ }^{7}$

Perhaps, too, Gunn is commenting, indirectly and by contrast, on his own poetic strategies and metaphors in "A Mirror for Poets." This poem, also in Fighting Terms, characterizes Elizabethan England as a culture of great violence, political intrigue, and contradictions between pomp and brutality, magnificence and squalor, Platonic ideals and actual disorder. Unlike the metaphoric situations in some of Gunn's other quasi-political poems, the Elizabethan realm described in "A Mirror for Poets" stimulates an exciting commerce between particular event and general significance:

In street, in tavern, happening would cry

6 See Monroe Spears's discussion of such metaphor in The Poetry of W. H. Auden: The Disenchanted Island (London and New York: Oxford University Press, 1968), pp. 34, 37.

7 Martin Dodsworth, "Taking Pleasure," The Listener, October 19, 1967, p. 506. 
'I am myself, but part of something greater,

Find poets what that is, do not pass by,

For feel my fingers in your pia mater. 8

Poets in Elizabethan and early Jacobean England, Gunn indicates, could relate to a social and conceptual order, a framework of transcendent beliefs that incorporated, clarified, and superseded the fluctuating violence and egotism of the age. The chief tension and excitement in "A Mirror for Poets" exist in this dialectic between historical disorder and Platonic transcendence, "Forms, flooding like moonlight, /In which the act or thought perceived its error" and in which "mankind might behold its whole extent." Yet Gunn, in holding up this era as a mirror or paradigm for poets, certainly cannot claim as such a mirror the existential world assumed in other poems. Lacking any tensive, suggestive relationship between particular event and a more broadly or deeply apprehended reality, his metaphoric situations often fold in upon an alienated self-consciousness.

In the world assumed by Gunn's poetry, self-containment, self-mastery, and self-assertion are frequent but ambiguous values. One of the most intriguing poems in Fighting Terms, "The Wound," deals with a debilitating split between reason and will. This "wound" of the poem's persona appears initially in terms of an Audenesque "moralized landscape": as in Auden's "Paysage Moralisé" or "In Memory of W. B. Yeats," Gunn stipulates a metaphoric relation between his speaker's psychic wound and a landscape containing valleys and villages. While the wound heals, the valleys darken and the villages remain quiet; but with the onset of wrath and the loss of self-control, the valleys are "storm-lit"-the cleft of the valleys presumably representing the cleavage between will and reason. This metaphorical geography, however, is incidental to the poem's basic pattern or vehicle, which is the Trojan War.

So long as the poem's speaker can maintain neutrality in this war, his wound remains closed and healing. To indicate lack of commitment and maintenance of reasonable control over the will, Gunn has his speaker fighting alternately "on both sides" of the war, changing identities as he switches allegiance between Trojans and Greeks. He is alternately Helen, Neoptolemus, and Achilles; the last figure, in his stubbornly proud independence, epitomizes the self-contained and self-mastering identity:

I was myself: subject to no man's breath:

My own commander was my enemy. ${ }^{9}$

When Thersites cackles the news of Patroclus's death, however, the wrath of Achilles causes him to lose control over his will and therefore his self-composure too. His wound re-opens. Thinking about Patroclus's "noble pain" induces rage, and once again the cleavage between reason and volition.

8 "A Mirror for Poets," Fighting Terms (New York: Hawk's Well Press, 1958), p. 35.

9 "The Wound," Fighting Terms, p. 11. 
Is commitment, with its attendant emotional risks or imbalance, nobler and more desirable than toughly isolated self-containment? Gunn's final poem in Fighting Terms, "Incident on a Journey," asserts a preference for willfully aggressive, tough-minded individuality. The red-coated soldier who appears as a dream-fetched alter ego of the poem's speaker says:

\section{And always when a living impulse came \\ I acted, and my action made me wise. \\ And I regretted nothing. ${ }^{10}$}

Regretting nothing is the refrain throughout this poem, a motto finally adopted by poet and persona alike. Action over self-conscious speculation, simplicity over complexity, and toughness over soft-hearted feeling are the preferences asserted here. Gunn's metrics tend to reinforce these values. The tight formality and strictly maintained stanzaic patterns of his poems in this volume imply containment, rigorous assertion, and a fear of emotional involvement or relaxation.

The Sense of Movement (1957), to my mind a much more impressive volume than Fighting Terms, shows a widening and slight shift of focus, yet relatively little change in poetic technique or strategy. That is, Gunn uses a greater range of situations and references to emblematize the dilemmas with which he is concerned. The terms and contrarieties of these dilemmas differ somewhat from those in Fighting Terms; Gunn's existentialism emerges more explicitly in this second volume. Yet there is the same dogged, willful manipulation of experiential data into allegory, the same stipulative insistence that Observation $\mathrm{X}$ or Situation Y must translate into Existential Doctrine Z. As M. L. Rosenthal writes about My Sad Captains, Gunn is preoccupied here "with existential emptiness on the one hand, and with the assertion of meaning through sheer will or willful action on the other. . ." 11 Again, this preoccupation is both the subject for certain poems in The Sense of Movement and a basis for Gunn's poetic method. Various personae in these poems try to assert and thus define themselves through their actions or movements, to break free of their imprisoning self-consciousness or passive intellectuality. At the same time Gunn, their creator and imaginative alter ego, tries to assert and define various meanings for the fictive situations they inhabit. That which is imposed, codified, and self-consciously manifested-whether it be a gesture, act, article of clothing, or poetic emblem-is that which assigns meaning to Gunn's subjects.

Such self-conscious assertion of meaning is both an energizing principle and a strait jacket for characters and poems in The Sense of Movement. The motorcycle boys and the young tough of "Market at Turk" are whipped into action by a need to assert their identities. Yet, as they "strap in doubt" or buckle themselves within surplus GI bootstraps and belts, they become tragi-comic poseurs: locked into self-willed immobility, costumed exemplars of Bergson's definition

10 "Incident on a Journey," Fighting Terms, p. 45.

11 M. L. Rosenthal, "Contemporary British Poetry," The New Poets: American and British Poetry Since World War II (New York, Oxford University Press, 1967), p. 256. 
for comedy, "the mechanical encrusted upon the living." Likewise the rhythms in many of these poems must struggle within or against arbitrary metrical and stanzaic patterns; the poet's concepts must struggle to manifest themselves within tangible circumstances, while seemingly random circumstances are mobilized and pressed to yield articulable ideas. Hence, I feel, the stiffly regular form and prosody in these poems. They are less a matter of "fashionable, rote prosody," as James Dickey labels them in his insensitive review, ${ }^{12}$ than an attempt to impose tangible order upon the materials of a world that is perpetually moving but without direction.

"On the Move," probably the best-known poem in The Sense of Movement, provides a good illustration of Gunn's energetic but arbitrary transition from initial circumstances to asserted significance. The motorcycle boys who are the poem's central personae, described distantly and objectively in the second stanza, become representative modern men, emblems for Gunn's existential selfhood, in later stanzas. Lacking the automatically fulfilled, instinctual purposes of birds and the transcendent, unwavering values of saints, "the Boys" are said to be "The self-defined, astride the created will." They are the poem's only embodiments of Gunn's quasi-philosophical statement that concludes stanza three and that we have quoted in part already:

Much that is natural, to the will must yield.

Men manufacture both machine and soul,

And use what they imperfectly control

To dare a future from the taken routes. ${ }^{13}$

Yet these exemplars of the human will are those who, in the preceding stanza, appear "Small, black, as flies hanging in heat" and who minimize risk or volition by strapping themselves "In goggles, donned impersonality,/ In gleaming jackets trophied by the dust." This is the poem's central weakness.

What originates as an objective, even judgmental view of the boys becomes an adulation of their existential daring. The transformation is a sudden, arbitrary one. A reader suspects that it is not really the motorcycle gang, or "Men" in general, who exercise their will in a valueless world; it is the poet, stipulatively shifting his perspective and attitude toward his subjects, who does so. The poem itself, rather than any motorcycle, provides the machinery by which meaning can be stipulated and human will asserted.

The assertion of will figures prominently also in "The Unsettled Motorcyclist's Vision of His Death." Here, again, the motorcycle itself serves as "chosen instrument" for the poem's persona. It is not a "valueless world" into which the cyclist hurls himself in this poem, however; it is a settled, habitual, insensate physical nature, a witless antagonist to the "unsettled" motorcyclist. Written in four-foot Marvellian couplets, this poem contains some of Gunn's finest descriptive and rhythmic effects, especially in its presentation of physical nature:

12 James Dickey, op. cit., p. 662.

13 "On the Move," op. cit., p. 11. 
I pick my way

Where death and life in one combine, Through the dark earth that is not mine, Crowded with fragments, blunt, unformed; While past my ear where noises swarmed The marsh plant's white extremities, Slow without patience, spread at ease Invulnerable and soft, extend With a quiet grasping toward their end.14

This relationship between human and non-human nature-one which Gunn explores more fully in his latest volume, Moly (1971)-allows the poet none of the "traditional" or "archetypal" metaphors and symbols in which natural phenomena (the seasons, the sun or moon, the springtime resurrection of plant-life, for example) furnish models or parallels for human concerns. Gunn's existentialism, at this stage of his career, seems resolutely set against any kind of preexisting "nature." Thus his poetry and poetic symbols are non-mythic or even anti-mythic: the self-conscious individual finds himself separate from animal or vegetative nature, often in defiant opposition to it. In "The Unsettled Motorcyclist's Vision ...." nature is an alien Otherness, a "mere embodiment." Tubers growing in the marsh fill out the cyclist's clothing, but

It is as servants they insist, Without volition that they twist;

And habit does not leave them tired,

By men laboriously acquired.

In "The Allegory of the Wolf Boy," another poem in The Sense of Movement, the persona's evasion of social and human identity involves his transformation into a werewolf, which relaxes his will in surrender to irrational nature. The wolf boy

$$
\text { goes beyond }
$$

His understanding, though the dark and dust:

Fields of sharp stubble, abandoned by machine

To the whining enmity of insect lust. 15

In a longer and more complex poem, "Merlin in the Cave: He Speculates Without a Book," the movement, sensuousness, and apparent spontaneity of natural phenomena-clouds, birds, grass, and bees-impress upon Merlin the decadent artificiality, the self-imprisoning role and sterile perfection of his mentalistic magicianship. To such an aesthetic dandy, immobilized in the cold perfection of

14 "The Unsettled Motorcyclist's Vision of His Death," The Sense of Movement, pp. 28-29.

15 "The Allegory of the Wolf Boy," The Sense of Movement, p. 35. 
his own calculated system, the struggle and flux of nature appear as attractive. alternatives. Yet Merlin ends his monologue by asserting human will and agency, rejecting both the "rank convolvulus" as a mode of escape from his cave and "the sweet promiscuity of the bee" as a model for his actions. A specific quality of nature-its dynamic movement-offers an example for human volition, but nature itself remains alien to the self-defining speaker of this poem.

Assuming this fundamental separation between human and non-human nature, Gunn often establishes artificial (man-made) situations as metaphoric extensions, emblems, or testing grounds for the human attributes he wishes to explore. "In Praise of Cities," for example, consciously elevates urban over natural landscape, the former being both a product and a multiple symbol of human desires and enterprise. "The Nature of an Action" utilizes two almost-identical furnished rooms as starting point and ultimate destination for its speaker's selfconscious progression. "The Corridor," in similar fashion, stipulates in its opening lines a metaphoric equation between setting and psyche:

A separate place between the thought and felt

The empty hotel corridor was dark. 16

Starting with this stipulated metaphoric equivalent, the poem explores a dilemma of self-consciousness that appears in several other poems of Gunn: a disjunction not so much between thinking and feeling as between acting and observing, spontaneity and self-awareness, self-abandon and self-control. The poem's development of this dilemma is ingenious and logical, once its terms have been established in the first two stanzas. A reader must, however, consent to the poet's stipulative imagination and its tactics before apprecating this poem.

The personae in Gunn's poetry, as we have already mentioned, also stipulate quasi-metaphoric "meanings" for themselves. Dress, mannerisms, jargon, and gestures are their modes for asserting self-elected, self-maintained identities. To create one's own personal identity in this way is often, as Oscar Wilde demonstrated in the late nineteenth century, to pose and to manifest various affectations. For this reason, probably, Gunn has been both hailed for his "toughness" and assailed for his chic dandyism. Pictured in a black leather jacket or sporting a Mephistophelean goatee, he is easily identified with the desperately or precociously assertive characters of his poetry. Because Gunn writes about "tough" characters, he is said to write "tough" poetry.

Perhaps it is true, as G. S. Fraser states in "The Poetry of Thom Gunn,"17 that there is far more self-assertion and risk-taking in Gunn's writing than in that of his compatriots such as Philip Larkin and Kingsley Amis. Yet there is also a formal, ironic distance, in some of his poems, between Gunn-the-poet and the self- or group-stipulated identities of his personae. Gunn might "think of all the toughs through history" in "Lines for a Book": he might assume the role of

16 "The Corridor," The Sense of Movement, p. 59.

17 G. S. Fraser, "The Poetry of Thom Gunn," Critical Quarterly III (Winter, 1961), pp. 359-367. 
a Sartrean hero in "Human Condition"; but he can also stand apart from such self-projections, objectively describing and implicitly judging them. He does this in "Market at Turk," as the following stanza shows:

\author{
It is military, almost, \\ how he buckles himself in, \\ with bootstraps and Marine belt, \\ reminders of the will, lest \\ even with that hard discipline \\ the hardness should not be felt. 18
}

"The Beaters," too, contains an explicit commentary on self-imposed, bizarre identities-and, by implication, on Gunn's own "violent parables" of stipulated meaning:

And what appear the dandy's affectation

-The swastika-draped bed, or links that press

In twined and gleaming weight beneath a shirt-

Are emblems to recall identity;

Through violent parables their special care

Is strictly to explore that finitude. 19

The final poem in The Sense of Movement, "Vox Humana," is one of Gunn's strongest performances, a gradually emerging manifestation of the existentialist belief that each human creature chooses, then fulfills, his own destiny or future. This future, the vox humana, is the poem's subtly insistent speaker which appears at first as "Being without quality" (note the grammatical pun on "Being"), "an unkempt smudge, a blur,/ an indefinite haze." After forcing itself upon human consciousness and choice, it takes on the most eminent distinguishing qualities of any individual who, in projecting his future, defines himself and stipulates his own fate. The poem reaches its rhetorical climax in the fourth stanza:

I was, for Alexander,

the certain victory; I

was hemlock for Socrates;

and, in the dry night, Brutus

waking before Philippi

stopped me, crying out 'Caesar!'20

To my judgment none of the poems in My Sad Captains, Gunn's next volume (1961), matches the best or most complex work in The Sense of Movement. The

18 "Market at Turk," The Sense of Movement, p. 32.

19 "The Beaters," The Sense of Movement, p. 36.

20 "Vox Humana," The Sense of Movement, p. 61. 
volume's opening poem, "In Santa Maria Del Popolo," receives the praise of M. L. Rosenthal and Ronald Hayman, ${ }^{21}$ but strikes me as insufficiently terse or compelling to justify the contrived associations on which it depends. Several other poems in the volume-"A Map of the City," "Black Jackets," and "Hotblood on Friday"-seem to be replays, with some variations, of subjects that Gunn had already dealt with in previous works. Other poems confront and explore a nagging problem which Gunn had touched upon in his two earlier volumes: the problem of language and conceptualization in a world where "meaning" derives from arbitrary linkage between words and referents, and where no natural consensus or basis for significance exists. It is a problem that arises when the stipulative imagination self-consciously examines its own practices.

The very title of Gunn's first book suggests, in its ambiguity, this problem. Fighting Terms: are these terms those against which one must fight, or are they expressions of one's pugnacity and combative energy? Are words a natural mode of communication, or enemies of sincerity and valid self-expression? A poet can stipulate-by context, convention, or sheer insistence-the metaphoric extensions of meaning his fictions are to convey. An individual can assert, through mannerisms or willful action, the identity or "meaning" he chooses for himself. Words themselves, however, cannot be wielded in quite so cavalier a fashion. They are social as well as personal, "natural" in their cultural and historical evolution, yet often shifting and arbitrary in their denotation of concepts, feelings, or perceptions. Moreover, the relationship between perception and conceptualization, between the sensible particulars of experience and the general abstractive terms with which language and thought operate, has become problematical in several systems or anti-systems of modern thought, from logical positivism to surrealism. Gunn's involvement in such issues starts early, but reaches something of a climax in My Sad Captains.

An early example of such involvement, from Fighting Terms, is "For a Birthday," the first two-thirds of which read:

I have reached a time when words no longer help:

Instead of guiding me across the moors

Strong landmarks in the uncertain out-of-doors,

Or like dependable friars on the Alp

Saving with wisdom and with brandy kegs,

They are gravel-stones, or tiny dogs which yelp

Biting my trousers, running around my legs.

Description and analysis degrade,

Limit, delay, slipped land from what has been;

And when we groan My Darling what we mean

Looked at more closely would too soon evade

The intellectual habit of our eyes;

21 Rosenthal, op. cit., p. 256; Hayman, op. cit., p. 72. 
And either the experience would fade

Or our approximations would be lies. ${ }^{22}$

Gunn's attitude toward words is quite explicit here, stated clearly in the opening lines of each stanza; but what about his use of language and metaphor? All but one line (the opening line) of the first stanza is quasi-metaphoric, using landscape, landmarks, friars, brandy kegs, gravel, and tiny dogs to enforce a simple contrast between useful and hindering words. All but three-fifths of one line (the second line) in the second stanza, by contrast, is expository and analytical. How does Gunn mingle or relate these two modes of writing: is there anything more than an arbitrary juncture between them, the ostensibly illustrative metaphoric language actually being less definite than the expository writing? (What does that second line of the second stanza actually convey, for example?) Given the clarity and potential impact of his literal subject, why did Gunn stipulate a pseudo-metaphoric set of equivalents for it? What transition between the "metaphoric" conclusion of the first stanza and the expository opening of the next stanza does the poem actually achieve?

This poem clearly distinguishes between words examined literally as words, and words translated into metaphoric equivalents or extensions (tiny dogs, gravel-stones). Several poems in The Sense of Movement, however, blur this distinction in a peculiar, arbitrary manner. These poems develop a definite situation and landscape as vehicle for whatever set of implications Gunn wishes to assert; "On the Move," for instance, uses motorcycle boys on a country road to represent the existential credo that Gunn ultimately wants to embody. Yet within this situation one of its literal components becomes identified as words. This happens in the final line of the first stanza of "On the Move":

One moves with an uncertain violence

Under the dust thrown by a baffled sense

Or the dull thunder of approximate words. ${ }^{23}$

The "dull thunder" would be that of the approaching motorcyclists, as the following stanza immediately indicates; yet Gunn stipulates another referent, "approximate words," for this noise. A later poem in The Sense of Movement, "Autumn Chapter in a Novel," opens with two characters-a beautiful French girl and a young tutor-strolling through autumnal woods, while "round their feet/ Mob syllables slurred to a fine complaint." This unexpected correlation between autumn leaves and desultory words recurs later in the poem:

Sap draws back inch by inch, and to the ground

The words they uttered rustle constantly:

Silent, they watch the growing, weightless mound. ${ }^{24}$

22 "For a Birthday," Fighting Terms, p. 44.

23 "On the Move," The Sense of Movement, p. 11.

24 "Autumn Chapter in a Novel," The Sense of Movement, p. 24. 
“The Separation," a poem based on Henry James's The Turn of the Screw, contains a similar correlation between landscape and language: "the trampled meadow of words."

Gunn's attitude toward words and language, then, often is one of suspicion or disgust. His poetry has been criticized for its abstractions; ${ }^{25}$ yet he has also been praised for his ability to take an image or situation and, "swinging rapidly between the particular and the general, to make it paradigmatic of the human condition." 26 Now there is nothing inherently wrong with abstractions in poetry, imagist doctrine to the contrary. Nor is there any automatic virtue in alternating between particulars and expository generalizations. At times, as in "For a Birthday," Gunn doesn't leave his abstract language well enough alone, his metaphoric "particulars" being the least justifiable or natural words in this poem. At other times the generalizations seemingly accumulated from specific situations are factitious or almost purely verbal. Conscious of this lack of organic or ontological connection between generalizing terms and definite experiential referents, Gunn wrote the following octave in "From the Highest Camp," a sonnet from My Sad Captains:

Nothing in this bright region melts or shifts.

The local names are concepts: the Ravine,

Pemmican Ridge, North Col, Death Camp, they mean

The streetless rise, the dazzling abstract drifts,

To which particular names adhere by chance,

From custom lightly, not from character.

We stand on a white terrace and confer;

This is the last camp of experience. ${ }^{27}$

Gunn's self-consciousness about language takes a different direction, also, in My Sad Captains. In the nominalistic realm of the "highest camp," or in a culture which has drained all dignity, precision, and social credibility from its abstract language, sensuous perception and particularity assume an exaggerated importance. They alone are "real"; they alone provide a trustworthy language of tangible, definite references that an individual can see, touch, or grasp. Thus an author like Ernest Hemingway and a literary character like Camus's Meursault in The Stranger strip both their vocabulary and their cognition of conceptualizations, writing or existing as fully as possible in a realm of immediate perceptions. Several of Gunn's poems in My Sad Captains display a similar immersion into phenomenological particularity: a radical cleansing of all pre-existing definitions, beliefs, and patternings of experience.

"Waking in a Newly-Built House" is such an exercise in perceptual immediacy; it is a minute examination of discrete sensory stimuli, the "newly-built

25 Johnson, op. cit., p. 518; Laurence Lieberman, "New Poetry in Review," Yale Review, Autumn 1968, p. 139.

26 Hayman, op. cit., p. 72.

27 "From the Highest Camp," My Sad Captains (Chicago: University of Chicago Press, 1961), p. 19. 
house" having removed the poem's speaker from all habitual associations and thus from any self-defining context. The only generalization Gunn allows himself is that which occurs in the poem's final stanza:

Calmly, perception rests on things, and is aware of them only in their precise definition, their fine lack of even potential meanings. 28

"Flying Above California," the poem that immediately follows, also effects a refreshing separation between concepts (highly connotative names of California cities, in this case) and perception. As the poem's speaker is flying above a semi-imaginary California, he breathes the names of places he has not been to: "Crescent City, San Bernardino//-Mediterranean and Northern names." Then a sudden shift occurs; the speaker's freely associating mind focuses sharply on "fogless days by the Pacific" where

there is a cold hard light without break

that reveals merely what is-no more and no less. That limiting candor,

that accuracy of the beaches, is part of the ultimate richness. ${ }^{29}$

"Considering the Snail" is a more complicated poem, inferring the snail's purposiveness from its stalwart push through moisture-laden grass; the poem ends with the assertion that perception alone would not suffice for any imaginings of the snail's "slow passion" or "deliberate progress." The poem rehearses a kind of paradox: its speaker-observer claims that his vision of the snail, in its sensuous particularity, would preclude any attribution of motive to this creature; yet obviously the poem itself contains more than mere perception or description.

In definite contrast to the group of poems just discussed is "The Byrnies," written by Gunn when he was studying Beowulf in a graduate class at Stanford and using the chain-mail armor of Geat tribesmen as its central symbol. These warriors are poised precariously against a hostile, mysterious, and monstrous nature, which threatens their emergent human intelligence as well as their physical security. Their byrnies protect them not only "Against the nicker's snap, and hostile spear," but also against the darkness of ignorance or superstition, and against "Barbaric forest, mesh of branch and root." The interlinking of metal bands which is their physical defense is also a linking of perceptions with concepts, particulars with generalization, into systematic thought and belief.

28 "Waking in a Newly-Built House," My Sad Captains, p. 33.

29 "Flying Above California," My Sad Captains, p. 34. 
Byrnie on byrnie! as they turned

They saw light trapped between the man-made joints,

Central in every link it burned,

Reduced and steadied to a thousand points.

Thus for each blunt-faced, ignorant one

The great grey rigid uniform combined

Safety with virtue of the sun.

Thus concepts linked like chainmail in the mind. ${ }^{30}$

Seen in retrospect and in relation to Gunn's two later volumes, My Sad Captains is a poetic dead end, a demonstration of self-consciousness and stipulative rhetoric played out to their limits. While The Sense of Movement appeared as an energetic, mature advance upon Fighting Terms, My Sad Captains adds little more than a deepened self-consciousness to the achievement of its predecessors. Gunn deals more critically and directly, in his third volume, with the limitations and arbitrary nature of self-stipulated identities or conceptualizations. At the same time his personae become more isolated in their perceptions, more rigidly compulsive in their modes of self-assertion, and altogether less admirable as models for existential action.

The shortcomings of My Sad Captains, in other words, are not wholly prosodic, though some critics jumped on Gunn's exclusive use of syllabic verse in the second half of the volume. ${ }^{31}$ Syllabic verse, however-especially as Gunn uses it-is not simply a prosodic alternative to traditional accentual-syllabic (footpatterned) lines. On the one hand it is a stripping-down of rhyme and meter to their barest essentials, reducing the recurrence of sound at the ends of lines to a minimum and doing away with any "carrying" rhythm within or between these lines. In several of his syllabic poems, as we have noted, Gunn performs an analogous reduction of content to a perceptual, phenomenological minimum. On the other hand, syllabic verse doggedly asserts the primacy of an arbitrary principle-a stipulated number of syllables for each line-as its structural basis. In defiance of any "natural" rhythm, the syllabic poet can create as truncated, hesitant, or discontinuous a movement as he pleases. I suggest, therefore, that Gunn's choice of syllabic meter parallels his choice of subject matter and ultimate concerns in My Sad Captains. As the poet or his persona reduces his vision to a perceptual minimum and his asserted identities to a narrow choice of gestures and actions, so he asserts a minimal but arbitrary metric for his verse.

If My Sad Captains pretty well exhausted any further possibilities for the stipulative self-consciousness and the self-defining "tough," where could Gunn's poetry go from there? Touch (1967), Gunn's next volume, provides a courageous answer or alternative. As Julian Symons wrote for The New Statesman:

There are no poems here praising all the toughs through history or tenderly analyzing sado-masochism, no threnodies for black-jacketed motor cy-

30 "The Byrnies," My Sad Captains, p. 34.

31 E.g., Anthony Thwaite, op. cit., p. 298. 
clists. Instead we have pieces which, almost for the first time in his work, suggest the possibility of tenderness between human beings, like the title poem with its relaxed rhythms. . . . 32

How can such tenderness be achieved, credibly and unsentimentally, in the sort of world envisioned by Gunn's previous poems? Or, in Symons's words, "How many hostages can be given to tenderness without damaging a vision whose quality is bound up with its hard assurance?"33

Gunn's major achievement to date, a seventeen-part poem called Misanthropos, answers this question. Misanthropos is far too long and complexly interrelated, in its parts and imagery, to discuss adequately here. What follows, instead, is a response to and partial modification of Merle Brown's critical enactment of the poem, which appears in this same issue.

In Misanthropos Gunn posits an existential and post-holocaustal isolation, and within this isolation a projection of himself. This self, in many ways a recognizable composite of the personae in Gunn's previous three volumes, is minimally human, isolated not only by external circumstances but also by his own misanthropy: his disgust for recent history, mass humanity, and the "dust" of human waste, futility, and cipherdom. Thus the physical privation of this "last man" functions in one sense as a stipulated metaphor for the psychological alienation and misanthropic fastidiousness of the "sensitive" modern artist, the alienated sensibility that subscribes to Waste Land attitudes toward contemporary life. This attitude is not merely the Anglo-Catholic superiority of a T. S. Eliot; it is an existential recoil of disgust from humanity stripped of all god-like attributes and of its participation in any transcendent order of being. As Nathan A. Scott wrote in The Broken Center:

What every reporter on the present human condition has . . to take into account is the sense that men have today of being thrust into the nudity of their own isolated existence. Though "huddled together" in the great metropolises of the contemporary "like dust in a heap," that which figures most prominently in their awareness is a sense of the world's vacancy, and the loss of the real proximity of friends and neighbors. ${ }^{34}$

This existential solitude, Scott believes, dates "from that morning when Baudelaire looked out upon the Paris landscape-'that vast cemetery that is called a great city'-and felt an immense disgust." 35 It is precisely this disgust, reinforced by a sense of superiority over "the masses" or "mass culture," that Gunn aims to excoriate and exorcise in Misanthropos.

In another sense, the circumstances in Misanthropos create not merely a metaphor but a frighteningly believable picture of existential misanthropy translated into political, military disaster. The poem presents a world of the "last

32 Julian Symons, "Clean and Clear," The New Statesman, October 13, 1967, p. 476.

33 Ibid., p. 476.

34 Nathan A. Scott, The Broken Center: Studies in the Theological Horizon of Modern Literature (New Haven: Yale University Press, 1966), pp. 16-17.

35 Ibid., p. 18. 
survivor," a neo-primitivism that one might envision himself entering when he leaves his backyard fallout shelter, a Darwinian survival prepared for by the most militantly individual character in James Dickey's novel Deliverance. It is both a fear and a secret fantasy of the isolated, self-assertive "tough" described in several of Gunn's earlier poems. In a world considered decadent and overpopulated, it is a retreat into "organic," "simple" nature, a life wiped clean of all over-civilized clutter and "mass" humanity.

In yet another sense, however, the "nature" in Misanthropos is essentially alien and thus destructive to human identity. Like the marshland described in "The Unsettled Motorcyclist's Vision of His Death" or the barbaric frost and salty hill in "The Byrnies," the physical setting in this poetic sequence is an insensate encroachment upon everything that would enable the "last man" to survive as a man. Memory and foresight, social role and individual self-consciousness, habit, gesture, and clothing or "uniform": all such attributes of Gunn's earlier dandies and self-assertive toughs are pitted against a dehumanizing nature, an isolating primitivism that is both metaphoric and very literal.

It is not brute survival that is at stake here; it is human reciprocity, community, relatedness, the interaction between knower and known, egotism and altruism. The landscape and diminishing outlook of misanthropy are not enough; nor is mere self-assertion. In two earlier poems of Touch, "Bravery" and "Confessions of the Life Artist," Gunn had turned his own bravado and aesthetic isolation into objects for critical self-examination. In Misanthropos these elements of himself and his past career become parts of a larger whole. The "last man" is both the poet himself and a fictive "representative man" of our contemporary age, as the dialogic form of Section II suggests-both "he" and "I," both the misanthropic element in Gunn and the anti-social, ingrown snobbery of modern racists, elitists, or men of "taste" and "discrimination." The "last man" in the poem is also the "first man"-the American Adam who must re-socialize himself, or at least reassert his social attributes while maintaining personal integrity, if he is to participate in the restoration of human community and civilization.

Each reader of Misanthropos must bring his own insight and background to this poem, as Merle Brown has done in his essay. Here I wish to call attention to only one of its parts, Section XII entitled "Elegy on the Dust." The poetry in this section is a remarkable combination of the meditative contemptu mundi tradition and the distinctively modern disgust for "mass man," which we have just discussed. Without resorting to stipulative allegory, Gunn moves gradually and convincingly from his description of a literal, post-nuclear sea of dust to a misanthropic view of modern humanity itself:

Each colourless hard grain is now distinct, In no way to its neighbour linked,

Yet from wind's unpremeditated labours It drifts in concord with its neighbours, Perfect community in its behavior. 
It yields to what it sought, a saviour:

Scattered and gathered, irregularly blown,

Now sheltered by a ridge or stone,

Now lifted on strong upper winds, and hurled

In endless hurry round the world. ${ }^{36}$

This section, the acme of misanthropy within the entire poem, still serves as a turning point for both Gunn and the "first man." If humans and their mass culture are a dust bowl, subject to the winds of fashion and political demagogues, they are also conscious of their common mortality: their companionate origin and rise from dust as well as their eventual return to it. It is the "first man's" recognition of this fact, in part, that enables him to struggle painfully against his isolated misanthropy in the last three sections of the poem.

Misanthropos as a whole is a prosodic tour de force, utilizing syllabic verse, rhymed couplets, quatrains, and occasional blank verse for its different sections, and thus lacking any metrical continuity or rationale. Each section, in effect, manifests Gunn's willful imposition of a specific rhyme scheme and a recognizable metric pattern upon its material. Other poems in Touch, however, notably the title poem and "Back to Life," show a relaxation of Gunn's tightly contained, strictly controlled verse-forms. As tough or highly conscious selfassertion yields gradually to a touch of gentleness in these poems, their prosody also yields some of its stipulated regularity.

In one sense, then, Touch seems divided into the "old" Gunn with his toughminded, rigorously controlled verse, and the "new" Gunn who moves toward sensuous, humane contact between existentially isolated beings. Yet the poems in Touch, organized as they are around Misanthropos, create a dialectic rather than a demarcation between isolation and contact, minimal individuality and interpersonal sympathy. For this reason I find Touch the most unified of Gunn's volumes to date.

In Moly, his most recent book (1971), Gunn returns to a relationship dealt with in earlier poems such as "The Allegory of the Wolf Boy," "The Byrnies," and "The Unsettled Motorcyclist's Vision of His Death": the relationship between human identity or consciousness and sub-human or "natural" forms of life. There is both a fear, a holding-back, and a temptation in this relationship. Gunn's personae, in various situations, perceive inhuman nature as either an encroachment upon, a release from, an arena for, or an extension of their individual personalities and wills. We have seen already that, for the willful existential self, there is no spontaneous, instinctual harmony with purely "natural" rhythms or forces, no return to mythic patterns of either metaphor or existence. The stipulative self, no matter how many elemental or phylogenetic components it subsumes, maintains its distinct identity as Gunn's unsettled motorcyclist does: by imposing itself, either as agent or viewer, against the nature that surrounds and partly inhabits it.

36 Section XII ("Elegy on the Dust") of Misanthropos, Touch (London: Faber \& Faber, 1967), p. 42. 
Just as there is a softening of self-asserted toughness in Touch, however, there are modifications in Moly of the polarity between human and inhuman nature. Moly, the supernaturally endowed herb given to Odysseus by Hermes, counteracts Circe's enchantment and restores Odysseus's men from swinehood back to humanity. Thus it becomes, in Gunn's title poem and throughout the volume itself, a talisman for transition and transformation.

Though certain poems in Moly express a nostalgic urgent desire to merge with unselfconscious nature, Gunn seldom relaxes the strict precision of their versification and stanzaic patterns. Gone are the free-verse rhythms of "Touch" and the loosely iambic movement of "Back to Life," two of Gunn's notable prosodic adventures in his previous volume. Gone too, in Moly, is the syllabic verse that figured so prominently in My Sad Captains and less noticeably in The Sense of Movement. The only departure from tightly patterned accentual-syllabic lines that Gunn allows himself is the paragraphed "prose-poetry" that occurs in "The Colour Machine" and in one section of "Tom-Dobbin."

At the same time that he tightens the formal prosody of these recent poems, Gunn also sharpens his focus on the sensory details and cumulative implications of the material with which they deal. By doing so, Gunn reduces the willful or stipulative attribution of meaning-the quasi-allegorical linking of descriptive details with authorially asserted values-that characterizes his earlier poetry. There is less self-consciousness in these poems: a greater trust in the intrinsic potential significance of events and situations. Although still largely estranged from the animal and vegetable kingdoms from which they have evolved, the human speakers in Moly no longer are the self-conscious toughs or dandies of Fighting Terms, The Sense of Movement, and My Sad Captains. Gunn's imagination can explore the boundaries between human and nonhuman nature rather than constantly, insistently stipulate its own identity or meanings. 